\title{
ISOLATION AND CHARACTERIZATION OF EDWARDSIELLA ICTAURI-SPECIFIC BACTERIOPHAGES
}

\author{
MAHMOUD MOSTAFA MAHMOUD ${ }^{1}$ and TOSHIHIRO NAKAI ${ }^{2}$ \\ ${ }^{1}$ Aquatic Animals Medicine and Management, Faculty of Veterinary Medicine, Assiut University, Assiut 71526, Egypt. \\ ${ }^{2}$ Fish pathology laboratory, Graduate School of Biosphere Science, Hiroshima University, Higashi-Hiroshima 739-8528, \\ Japan
}

Received: 31 March 2019; Accepted: 7 April 2019

\begin{abstract}
The present study aimed to isolate and characterize bacteriophages (phages) specific for Edwardsiella ictaluri to be used as a biological control of the infection in fish as a final goal. Twenty-six phages (PEi1 PEi26), lytic to E. ictaluri were isolated from ayu Plecoglossus altivelis and its surrounding environment (water and mud) using enrichment and double agar layer methods. All phages formed clear plaques ranging in size from 0.3 to $8 \mathrm{~mm}$ in diameter. Transmission electron microscopy revealed that all the isolated bacteriophages belonged to the family Myoviridae. According to phage morphology, plaques size and DNA restriction patterns with EcoRI, the phages were classified into four groups $(\mathrm{I} \sim \mathrm{IV})$. E. ictaluri strains isolated from ayu $(\mathrm{n}=57)$ were sensitive to these phages with various degrees, resulting in twenty-five phage types of the bacterium. E. ictaluri strains isolated from catfish in the USA (type strain; JCM1680), Indonesia $(n=4)$ or Vietnam $(n=2)$ exhibited no or very limited susceptibility to the present phages. In addition, E. tarda, the most closely related species to E. ictaluri, as well as other fish pathogens were not susceptible to any of the phages examined.
\end{abstract}

Key words: E. ictaluri specific-bacteriophage, TEM, phage typing, host range, restriction enzyme

\section{INTRODUCTION}

Edwardsiella ictaluri, the causative agent of enteric septicemia of catfish (ESC), was first isolated from pond-reared channel catfish Ictalurus punctatus in 1976 in the USA (Hawke, 1979), characterized and classified by Hawke et al. (1981). Subsequently, E. ictaluri was reported from several natural outbreaks in non-ictalurid hosts including green knife fish Eigemannia virscens (Kent and Lyons, 1982), danio Danio devario (Waltman et al., 1985), and tadpole madtom Noturus gyrinus in the United States (Klesius et al., 2003), walking catfish Clarias batrachus in Thailand (Kasornchandra et al., 1987), striped catfish Panagassius hypophthalmus in Vietnam (Crumlish et al., 2002; Ferguson et al., 2001) and in Indonesia (Yuasa et al., 2003), rainbow trout Oncorhynchus mykiss in Turkey (Keskin et al., 2004), yellow catfish Pelteobagrus fulvidraco in China (Ye et al., 2009) and the bacterium was recently isolated from wild Australian catfish Tandanus tropicanus (Kelly et al., 2018).

In Japan, Edwardsiella ictaluri was isolated for the first time in 2007 from natural outbreaks in wild

Corresponding author: Dr. Mahmoud Mostafa Mahmoud E-mail address: mahmoud88@ aun.edu.eg

Present address: Aquatic Animals Medicine and Management, Faculty of Veterinary Medicine, Assiut University, Assiut 71526, Egypt.
Japanese ayu Plecoglossus altivelis populations and the disease was described as E. ictaluri-infection in ayu (Sakai et al., 2008). Subsequently, phenotypical and genetic characterization of the isolated strains were carried out. All the tested isolates $(n=4)$ were identical in morphological, physiological, biochemical and genetic characters (Nagai et al., 2008). Moreover, the pathogen was isolated from apparently healthy wild ayu and forktail bullhead Pseudobagrus nudiceps from Gonokawa River in Hiroshima Prefecture, Japan in two successive years; 2008 and 2009, with isolation rate of $30.5 \%$ and $23.5 \%$ respectively (Hassan et al., 2012). All E. ictaluri isolates $(\mathrm{n}=128)$ from ayu and a strain from forktail bullhead, collected from different localities in Japan, were identical physiologically, biochemically; except for $\mathrm{H}_{2} \mathrm{~S}$ production; and genetically using the partial nucleotide sequences of a Type 1 fimbrial gene cluster ( tf $A$, etf $B$, etf $C$, etfD), and random amplified polymorphic DNA (RAPD) analysis (Hassan et al., 2012). Also, these isolates were serologically the same (Hassan et al., 2010). Thus, another method for differentiation of these strains was still needed. Therefore, the current work was directed to isolate and characterize E. ictalurispecific phages for further characterization of the present E. ictaluri strains isolated from ayu. Also, detection of specific phages may help in control of infection caused by this pathogen. 


\section{MATERIALS AND METHODS}

\section{Fish Samples:}

A total number of 295 apparently healthy wild ayu (average standard length \pm standard deviation [SD] of $178.0 \pm 19.0 \mathrm{~mm}$ and average body weight $\pm \mathrm{SD}$ of $81.8 \pm 26.0 \mathrm{~g}$ ) were caught by gill net from the Gonokawa River, Miyoshi City-Hiroshima Prefecture, Japan. The fish were collected monthly (average 25 fish per month). Fish were transported to the Laboratory of Fish Pathology, Hiroshima University, on ice, and phage isolation from kidney was carried out.

\section{Environmental samples:}

Water and mud samples (200 mL; $\mathrm{n}=12$ ) were collected in sterile bottles from the same place of the fish sampling (Gonokawa River, Myioshi cityHiroshima Prefecture). Also, pond water samples $(200 \mathrm{~mL})$ were collected from cultured ayu farms $(\mathrm{n}=11)$ in Tokushima, Shiga and Wakayama prefectures and subject to bacteriophage isolation.

\section{Bacterial strains and media:}

Strains of E. ictaluri used in this study are listed in Table 1. They include strains isolated from wild ayu at different localities in Japan, the type strain JCM1680 (ATCC33202) of E. ictaluri isolated from channel catfish, and six E. ictaluri strains isolated from striped catfish in Indonesia, and Vietnam (Hassan et al., 2012). All strains were further confirmed as E. ictaluri using using polymerase chain reaction (PCR) with an E. ictaluri-specific primer set, EDi (EDi-F: 5' CAGATGAGCGGATTTCACAG- 3'; EDi-R: 5'CGCGCAATTAACATAGAGCC-3'), that targets the upstream region of the fimbrial gene cluster $(470$ bp) as was described by Sakai et al. (2009). Also, four strains of the closely related fish pathogen, $E$. tarda including the type strain (JCM1656= ATCC15947), and some other fish pathogens were used (Table 1). Heart infusion broth (HIB; Nissui, Japan), soft agar (Trypto-soy broth, TSB; Eiken, Japan supplemented with $0.35 \%$ agar) and Tryptosoya agar (TSA; Nissui) were used for bacterial culture and bacteriophage plaque forming unit (PFU) assay (Carlson, 2005). All strains were kept at $-80^{\circ} \mathrm{C}$ in HIB containing $25 \%$ glycerol until being used. Prior to experiments, the strains were inoculated on TSA directly from $-80^{\circ} \mathrm{C}$ and incubated at $30^{\circ} \mathrm{C}$ for 48 hours.

\section{Isolation of $E$. ictaluri phage and PFU assay:}

An enrichment method described previously (Carlson, 2005) was employed to isolate E. ictaluri phages from the natural environment (water and mud) as well as from the kidney of apparently healthy wild ayu. In brief, pooled kidney samples from wild ayu were inoculated in HIB supplemented with $E$. ictaluri as host cells. Unless otherwise mentioned, five strains of E. ictaluri; D4, AH0801,
AH0816, PH0744 isolated from wild ayu in addition to Oth.29 isolated from forktail bullhead (Hassan et al., 2012), were used as host bacteria. Each environmental sample $(200 \mathrm{ml})$ was mixed with the same volume of double strength HIB provided with the host cells. After being incubated at $25^{\circ} \mathrm{C}$ overnight in a static condition, the culture was centrifuged at 5,000 rpm for $30 \mathrm{~min}$ at $4{ }^{\circ} \mathrm{C}$., and the supernatant was filtered using $0.45 \mu \mathrm{m}$ cellulose filter (Advantec ${ }^{\circledR}$, Japan). The presence of lytic phages in the filtrate was detected by the spot method with the double agar layer (Carlson, 2005). Briefly, $400 \mu \mathrm{l}$ of $E$. ictaluri cells in the exponential growth phase were mixed with $3 \mathrm{ml}$ of $50^{\circ} \mathrm{C}$ top soft agar (TSB with $0.35 \%$ agar), and the mixture was poured onto a TSA plate. After solidification (around $30 \mathrm{~min}$ ), $20 \mu \mathrm{l}$ of the filtrate (spot) was inoculated onto the double agar layer plate and the plate was incubated at $25^{\circ} \mathrm{C}$ overnight. The sample was scored positive for the presence of lytic phage if a clear zone or plaque was detected in the bacterial lawn of the plate.

\section{Phage cloning:}

A single plaque was picked up with a sterile loop and inoculated into HIB supplemented with one strain of E. ictaluri. Each phage was isolated as a single clone by three cycles of plaque purification and re-infection. For determination of phage concentration, 10-fold serial phage dilutions in phosphate buffered saline (PBS, $0.01 \mathrm{M}, \mathrm{pH}$ 7.4) were used and inoculated onto double agar layer (Carlson, 2005). All assays were performed in triplicates.

\section{Electron microscopy of phage:}

Following the method described by Kawato et al. (2015), fifteen microliters of a phage suspension were spotted on top of a formvar-carbon-coated copper grid, and the phage was allowed to adsorb for 10 seconds. Excess amount was removed carefully by touching the side of the grid with filter paper. The sample was washed three times with sterile filtered distilled water and stained by the addition of $8 \mu \mathrm{L}$ of $2 \%$ uranyl acetate $(\mathrm{pH} 4)$. Excess stain was removed, and the grid was allowed to air dry for $10 \mathrm{~min}$. The grids were observed using transmission electron microscope (JEOL, JEM-1200EX, Japan) at $80 \mathrm{KV}$.

\section{Determination of the phage host range:}

Strains of E. ictaluri $(\mathrm{n}=57)$ isolated from ayu (Hassan et al., 2012), Japan, were used in this study (Table 1). Other E. ictaluri strains from Indonesia $(n=4)$, Vietnam $(n=2)$, one strain from the USA as well as some other fish pathogenic bacteria including E. tarda $(\mathrm{n}=4)$, Vibrio parahemolyticus, Pseudomonas plecoglossicida, Streptococcus iniae, and Lactococcus garvieae were also used for comparison. The host ranges of the isolated phages were determined by the spot method (Carlson, 2005) where $20 \mu \mathrm{l}$ containing $5 \times 10^{5} \mathrm{PFU}$ of each phage 
suspension was spotted on top agar layer of TSA plate that is freshly prepared with $3 \mathrm{ml}$ of top agar inoculated with $400 \mu \mathrm{l}$ of the strain to be tested. The host range was determined with three separate plates for each phage-host combination, and all bacterial strains were tested against all the phage isolates.

\section{Analysis of the phage nucleic acids:}

Extraction and purification of phage nucleic acid: Extraction and purification of phage nucleic acid was carried out as described previously (Carlson, 2005) with slight modification. Briefly, phage was propagated with its host strain in $300 \mathrm{ml}$ of HIB medium and incubated at $25^{\circ} \mathrm{C}$ overnight. After removal of the bacterial debris by mild centrifugation at $5,000 \mathrm{rpm}$ at $4{ }^{\circ} \mathrm{C}$ for $30 \mathrm{~min}$ and passage through $0.45 \mu \mathrm{m}$ filter, the filtrate was supplemented with polyethylene glycol 6000 (Nacalai Tesque, Japan) and $\mathrm{NaCl}$ at final concentrations of $10 \%$ and $0.5 \mathrm{M}$, respectively, and incubated at $4{ }^{\circ} \mathrm{C}$ overnight. Phage was precipitated by centrifugation $\left(15,000 \mathrm{rpm}, 4^{\circ} \mathrm{C}, 15 \mathrm{~min}\right)$ and the precipitate was suspended in $0.5 \mathrm{ml}$ diluent $[0.01 \mathrm{M}$ Tris- $\mathrm{HCl}$ (pH 7.4), $0.15 \mathrm{M} \mathrm{NaCl}, 0.03 \%$ (w/v) gelatin]. Finally, phage was sequentially purified by cesium chloride $(\mathrm{CsCl})$ step gradient ultracentrifugation $\left(45,000 \mathrm{rpm}, 4^{\circ} \mathrm{C}, 18 \mathrm{~h}\right)$ using the S80AT3 rotor and a GX series Himac CS 100GX microultracentrifuge (Hitachi Ltd., Tokyo, Japan). After collection of phage band, the purified phage was dialyzed with PBS $(0.01 \mathrm{M}, \mathrm{pH} 7.4)$ three times at 1-hour interval. To the dialyzed phage, proteinase $\mathrm{K}$ was added to a final concentration of $50 \mu \mathrm{g} / \mathrm{ml}$ and sodium dodecyl sulfate (SDS) to a final concentration of $0.5 \%$ and incubated at $56^{\circ} \mathrm{C}$ for 1 hour. The protein was removed by two phenol saturated TE buffer (10 mM Tris-HCl, $\mathrm{pH} 8.0,1 \mathrm{mM}$ EDTA), chloroform-isoamyl alcohol (25:24:1) extractions. The nucleic acid was precipitated by the addition of a 0.1 volume of $3 \mathrm{M}$ sodium acetate and a 2.5 volume of absolute cold ethanol and the mixture was incubated at $-20^{\circ} \mathrm{C}$ overnight, followed by centrifugation at $14,000 \mathrm{rpm}\left(10 \mathrm{~min}, 4^{\circ} \mathrm{C}\right)$. The DNA pellet was washed twice with $70 \%$ ethanol, dried and finally dissolved in 50 to $100 \mu \mathrm{L}$ of $\mathrm{TE}$ buffer ( $\mathrm{pH} 8.0)$.

\section{Restriction enzyme digestion of the phage nucleic acids:}

The purified nucleic acid was tested for sensitivities to RNase A $(20 \mu \mathrm{g} / \mathrm{ml})$, DNase I $(20 \mu \mathrm{g} / \mathrm{ml})$, and the restriction enzyme EcoRI $(20 \mu \mathrm{g} / \mathrm{mL})$ by incubation at $37^{\circ} \mathrm{C}$ for $30 \mathrm{~min}$. Samples were analyzed along with undigested phage DNA. The resulting product was electrophoresed through $1 \%$ agarose gel at $50 \mathrm{~V}$ and visualized by ethidium bromide.

\section{RESULTS}

\section{Phage isolation:}

A total of 26 E. ictaluri-lytic phages (Table 2) were isolated from wild ayu (kidney) and the surrounding environment (mud and water) by the enrichment method. The isolated phages were designated as PEi1 PEi26. They formed clear plaques on double agar layer ranged in size from 0.3 to $8 \mathrm{~mm}$ in diameter (Fig. 1). E. ictaluri phages were found in all samples examined from wild ayu and their natural environment but not from cultured ayu $(n=11$ farms) in Wakayama, Shiga and Tokushima prefectures.

\section{Phage morphology:}

Transmission electron microscopy of negativelystained phage isolates revealed that all of them belonged to family Myoviridae that is characterized by head and contractile tail with spikes (Table 3, Fig. 2). According to the number of phage isolates within each group, phages were classified into four groups (group I IV) where group I included the majority of the isolated phage $(n=19)$ that produced clear plaques on double agar layer, ranged from 1.5-2.5 $\mathrm{mm}$ in diameter and characterized by isometric head and relatively short tail (< $60 \mathrm{~nm})$; group II comprised five phage isolates that produced hazy big plaques (5-8 $\mathrm{mm}$ in diameter) and characterized by isometric head and relatively larger tail (> 80nm); group III consisted of two phage isolates that produced round clear plaques $(0.5-1 \mathrm{~mm}$ in diameter) and had big elongated head and long tail (> 120nm), and group IV that had only one phage and form very small plaques $(0.3-0.4 \mathrm{~mm}$ in diameter) and characterized by elongated head and long tail (>120 nm; Fig. 1 and 2).

\section{Host range and phage typing of the bacterium:}

The host ranges of the isolated phages, tested against different E. ictaluri strains (Table 1) isolated from different fish species, are shown in Fig. 3. The phages were able to lyse all E. ictaluri strains isolated from ayu (Japan), but not those isolated from other countries (USA, Indonesia, and Vietnam) and this resulted in twenty-five phage types of the bacteria with two major phage types; phage type one and two that were represented respectively by 13 and 12 strains of E. ictaluri isolated from ayu (Table 4). None of the tested E. tarda strains as well as the other fish pathogenic bacteria was lysed by any of these phages.

\footnotetext{
Analysis of the phage nucleic acids:

The nucleic acids of the isolated phages were digested by DNase I but not by RNase A and cleaved by EcoRI (except EPi20 and EPi26) resulting in various restriction patterns among different phage groups and same restriction pattern among individuals of the same group (Fig.4).
} 
Table 1. Sources of bacterial strains used in this study

\begin{tabular}{|c|c|c|c|}
\hline \multirow{2}{*}{ Bacterial strain } & \multicolumn{3}{|c|}{ Source } \\
\hline & Host fish & Locality & Year \\
\hline \multicolumn{4}{|l|}{ Edwardsiella ictaluri } \\
\hline $\mathrm{JCM} 1680^{a}$ & Channel catfish $^{b}$ & Georgia, USA & 1976 \\
\hline JF0207 & Striped catfish $^{c}$ & Indonesia & 2002 \\
\hline JF0381 & Striped catfish & Indonesia & 2003 \\
\hline JF0384 & Striped catfish & Indonesia & 2003 \\
\hline JF0378 & Striped catfish & Indonesia & 2003 \\
\hline DTHN01 & Striped catfish & Vietnam & 2009 \\
\hline DTHN04 & Striped catfish & Vietnam & 2009 \\
\hline FPC1091 & Diseased Ayu ${ }^{d}$ & Yamaguchi Pref., Japan & 2007 \\
\hline FPC1092 & Diseased Ayu & Tokyo, Japan & 2007 \\
\hline FPC1093 & Diseased Ayu & Tokyo, Japan & 2007 \\
\hline PH0744 (FPC1094) & Diseased Ayu & Hiroshima Pref., Japan & 2007 \\
\hline FPC1095 & Ayu & Shimane Pref., Japan & 2008 \\
\hline FPC1096 & Ayu & Shimane Pref., Japan & 2008 \\
\hline FPC1097 & Ayu & Shimane, Pref. Japan & 2008 \\
\hline FPC1098 & Ayu & Gifu Pref., Japan & 2008 \\
\hline FPC1099 & Ayu & Tottori Pref., Japan & 2008 \\
\hline FPC1100 & Ayu & Tottori Pref., Japan & 2008 \\
\hline FPC1101 & Ayu & Tokyo, Japan & 2008 \\
\hline FPC1102 & Ayu & Tokyo, Japan & 2008 \\
\hline FPC1103 & Ayu & Okayama Pref., Japan & 2008 \\
\hline D4 & Dead Ayu & Hiroshima Pref., Japan & 2008 \\
\hline AH0801-AH0890 (n=90) & Healthy Ayu & Hiroshima Pref., Japan & 2008 \\
\hline AH0901-AH0954 (n=12) & Healthy Ayu & Hiroshima Pref., Japan & 2009 \\
\hline Oth.29 & Forktail bullhead $^{e}$ & Hiroshima Pref., Japan & 2008 \\
\hline 0801 & Ayu & Tokushima Pref., Japan & 2008 \\
\hline 0803 & Ayu & Tokushima Pref., Japan & 2008 \\
\hline KY-7 & Ayu & Kyoto Pref., Japan & 2009 \\
\hline WY-2 & Ayu & Wakayama Pref., Japan & 2009 \\
\hline TY-1 & Ayu & Toyama Pref., Japan & 2009 \\
\hline TG-7 & Ayu & Tochigi Pref.., Japan. & 2009 \\
\hline $\mathrm{KC}-4$ & Ayu & Kochi Pref., Japan & 2009 \\
\hline GF-2 & Ayu & Gifu Pref., Japan & 2009 \\
\hline \multicolumn{4}{|l|}{ E. tarda } \\
\hline FK1051 & Japanese flounder & Hiroshima Pref., Japan & 2003 \\
\hline NUF251 & Japanese flounder & Nagasaki Pref., Japan & 1986 \\
\hline SU-100 & Japanese eel & Shizuoka Pref., Japan & 1980 \\
\hline $\mathrm{JCM} 1656^{f}$ & Type strain & & 1982 \\
\hline Vibrio parahemolyticus & Ayu & Japan & 1987 \\
\hline Pseudomonas plecoglossicida & Ayu & Hiroshima Pref., Japan & 1995 \\
\hline Streptococcus iniae & Japanese flounder & Japan & 1983 \\
\hline Lactococcus garvieae & Yellowtail & Ehime Pref., Japan & 2002 \\
\hline
\end{tabular}

${ }^{a} \mathrm{JCM}$, Japan Collection of Microorganisms (=ATCC33202), ${ }^{b}$ Ictalurus punctatus ${ }^{c}$,Pangasius hypophthalmus

${ }^{d}$, Plecoglossus altivelis, ${ }^{e}$ Pseudobagrus nudiceps, ${ }^{f}=$ ATCC 15947. 
Table 2. Edwardsiella ictaluri phages isolated from wild ayu (kidney) and its surrounding environment

\begin{tabular}{|c|c|c|c|c|}
\hline Isolation from & Phage No. & $\begin{array}{l}\text { E. ictaluri } \\
\text { (host cell) }\end{array}$ & $\begin{array}{l}\text { Plaque size } \\
\text { (mm) }\end{array}$ & $\begin{array}{c}\text { Bacterial No. lysed by } \\
\text { phage (out of 57) }\end{array}$ \\
\hline \multirow{4}{*}{ Fish } & PEi3 & AH0801 & $1.5-2.5$ & 46 \\
\hline & PEi6 & Oth29 & $1.5-2.5$ & 51 \\
\hline & PEi13 & AH0816 & $1.5-2.5$ & 51 \\
\hline & PEi23 & D4 & $1.5-2.5$ & 50 \\
\hline \multirow{13}{*}{ Water } & PEi2 & Oth29 & $1.5-2.5$ & 51 \\
\hline & PEi4 & AH0801 & $1.5-2.5$ & 51 \\
\hline & PEi7 & Oth29 & $1.5-2.5$ & 51 \\
\hline & PEi8 & Oth29 & $1.5-2.5$ & 51 \\
\hline & PEi10 & AH0816 & $1.5-2.5$ & 44 \\
\hline & PEi12 & D4 & $1.5-2.5$ & 49 \\
\hline & PEi14 & D4 & $1.5-2.5$ & 51 \\
\hline & PEi15 & PH0744 & $1.5-2.5$ & 51 \\
\hline & PEi17 & Oth29 & $0.3-0.4$ & 51 \\
\hline & PEi18 & Oth29 & $5-8$ & 18 \\
\hline & PEi21 & AH0816 & $5-8$ & 24 \\
\hline & PEi22 & AH0816 & $1.5-2.5$ & 52 \\
\hline & PEi25 & AH0816 & $5-8$ & 43 \\
\hline \multirow{9}{*}{ Mud } & PEi1 & Oth29 & $1.5-2.5$ & 51 \\
\hline & PEi5 & Oth29 & $1.5-2.5$ & 51 \\
\hline & PEi9 & АH0816 & $1.5-2.5$ & 51 \\
\hline & PEi11 & PH0744 & $1.5-2.5$ & 49 \\
\hline & PEi16 & Oth29 & $1.5-2.5$ & 51 \\
\hline & PEi19 & Oth29 & $5-8$ & 42 \\
\hline & PEi20 & Oth29 & $0.5-1$ & 49 \\
\hline & PEi24 & Oth29 & $1.5-2.5$ & 50 \\
\hline & PEi26 & AH0816 & $0.5-1$ & 49 \\
\hline
\end{tabular}

Table 3. Morphological characteristics of the isolated Edwardsiella ictaluri phages

\begin{tabular}{cccccc}
\hline Group & $\begin{array}{c}\text { Head diameter } \\
(\mathrm{nm})\end{array}$ & $\begin{array}{c}\text { Head length } \\
(\mathrm{nm})\end{array}$ & Tail diameter $(\mathrm{nm})$ & $\begin{array}{c}\text { Tail length } \\
(\mathrm{nm})\end{array}$ & Family \\
\hline I & $55.2 \pm 12.2$ & $52.5 \pm 8.1$ & $19.5 \pm 2.0$ & $59.6 \pm 2.8$ & Myoviridae \\
II & $69.4 \pm 3.9$ & $66.6 \pm 0.0$ & $22.15 \pm 7.8$ & $81.95 \pm 9.8$ & Myoviridae \\
III & $87.4 \pm 5.0$ & $100.8 \pm 9.3$ & $28.6 \pm 3.8$ & $129.7 \pm 8.2$ & Myoviridae \\
& & & & & \\
IV & $80.6 \pm 4.8$ & $109.8 \pm 4.7$ & $26.4 \pm 2.4$ & $127.7 \pm 9.6$ & Myoviridae \\
\hline
\end{tabular}


Table 4. Phage typing scheme of Edwardsiella ictaluri

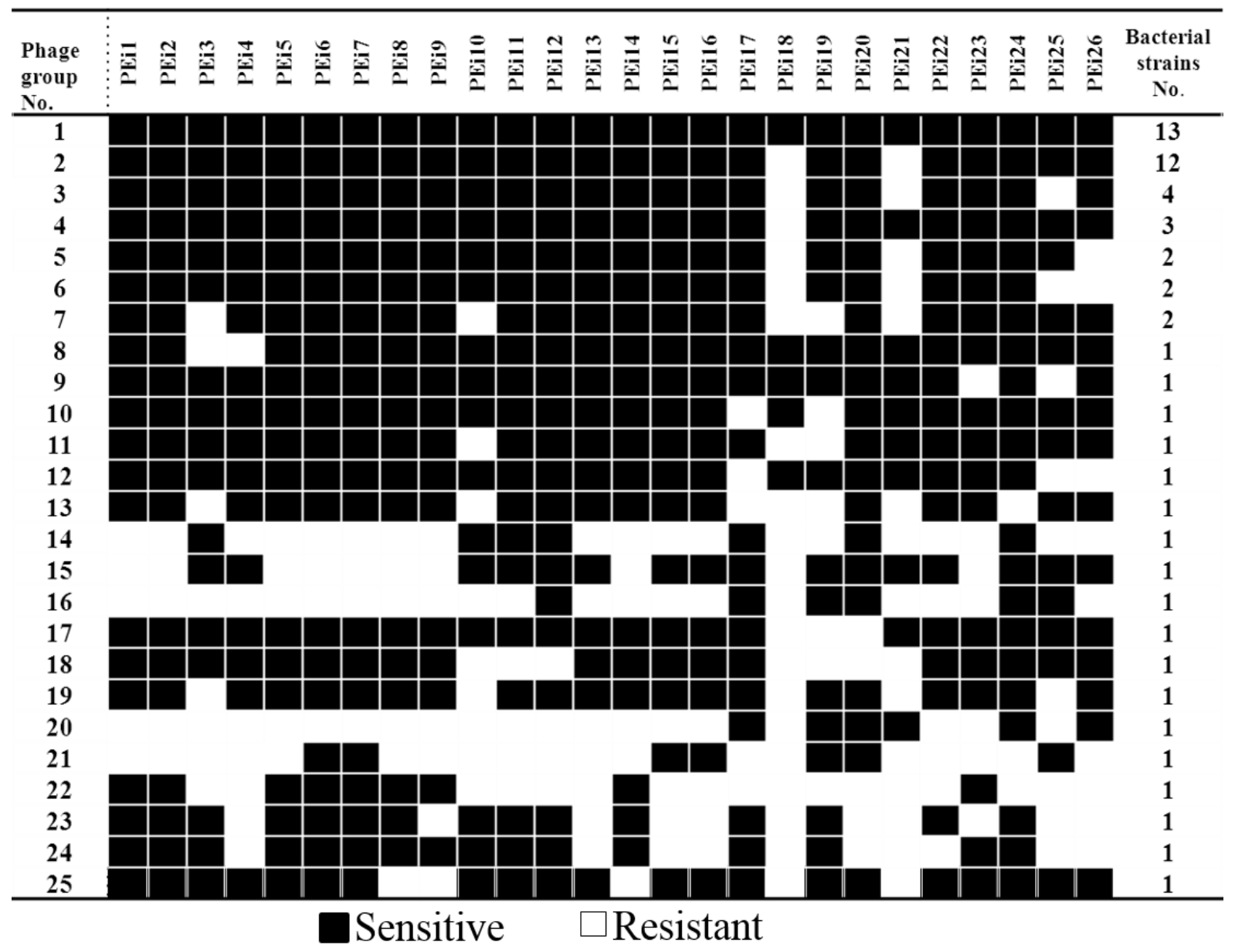

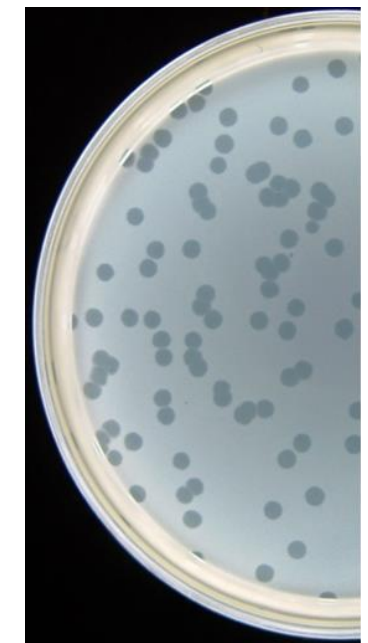

Group I

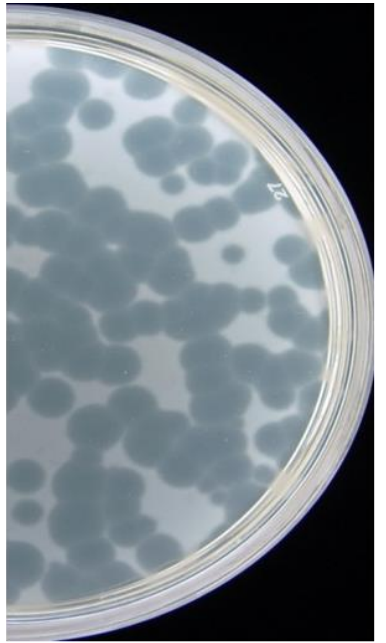

Group II

5-8mm

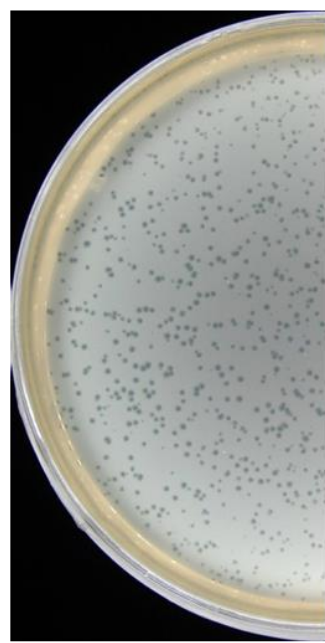

Group III

0.5-1 mm

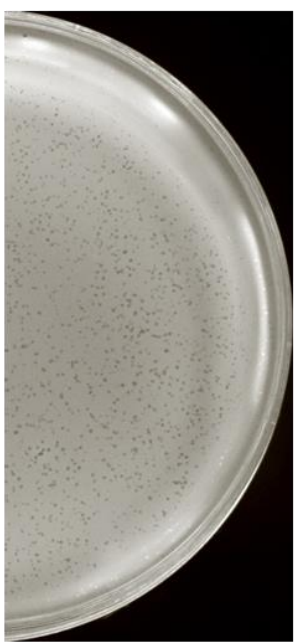

Group IV

$0.3 \mathrm{~mm}$

Fig. 1: Plaques of representative Edwardsiella ictaluri bacteriophages on a double agar layer. Phages were classified into four groups based on their abundance and plaque sizes. 

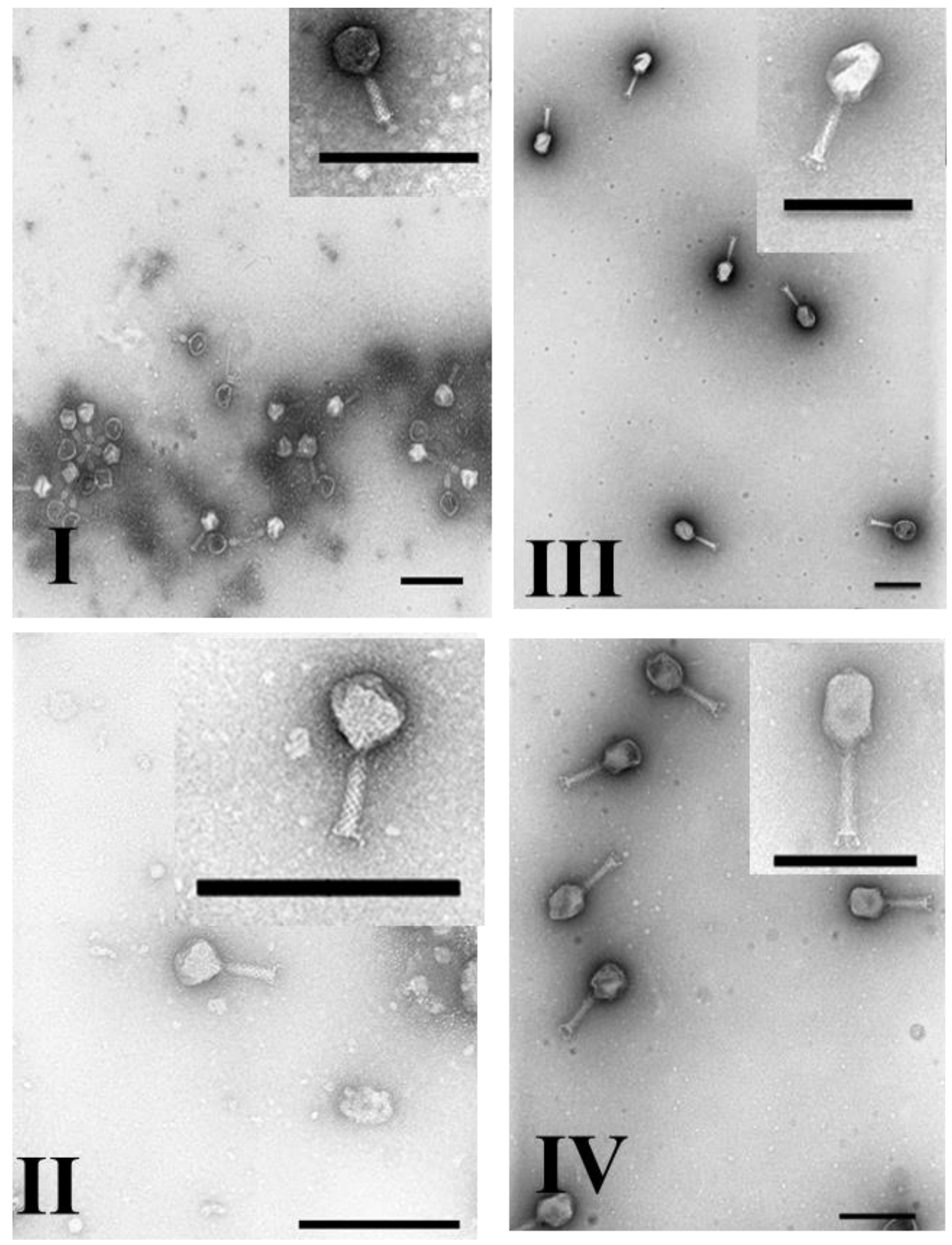

Fig. 2: Transmission electron microscopy (TEM) picture of representative Edwardsiella ictaluri phages (A) PEi1 (Group I); (B) PEi19 (Group II); (C) PEi17 (Group III); (D) PEi20 (Group IV). Scale bar=200 nm 


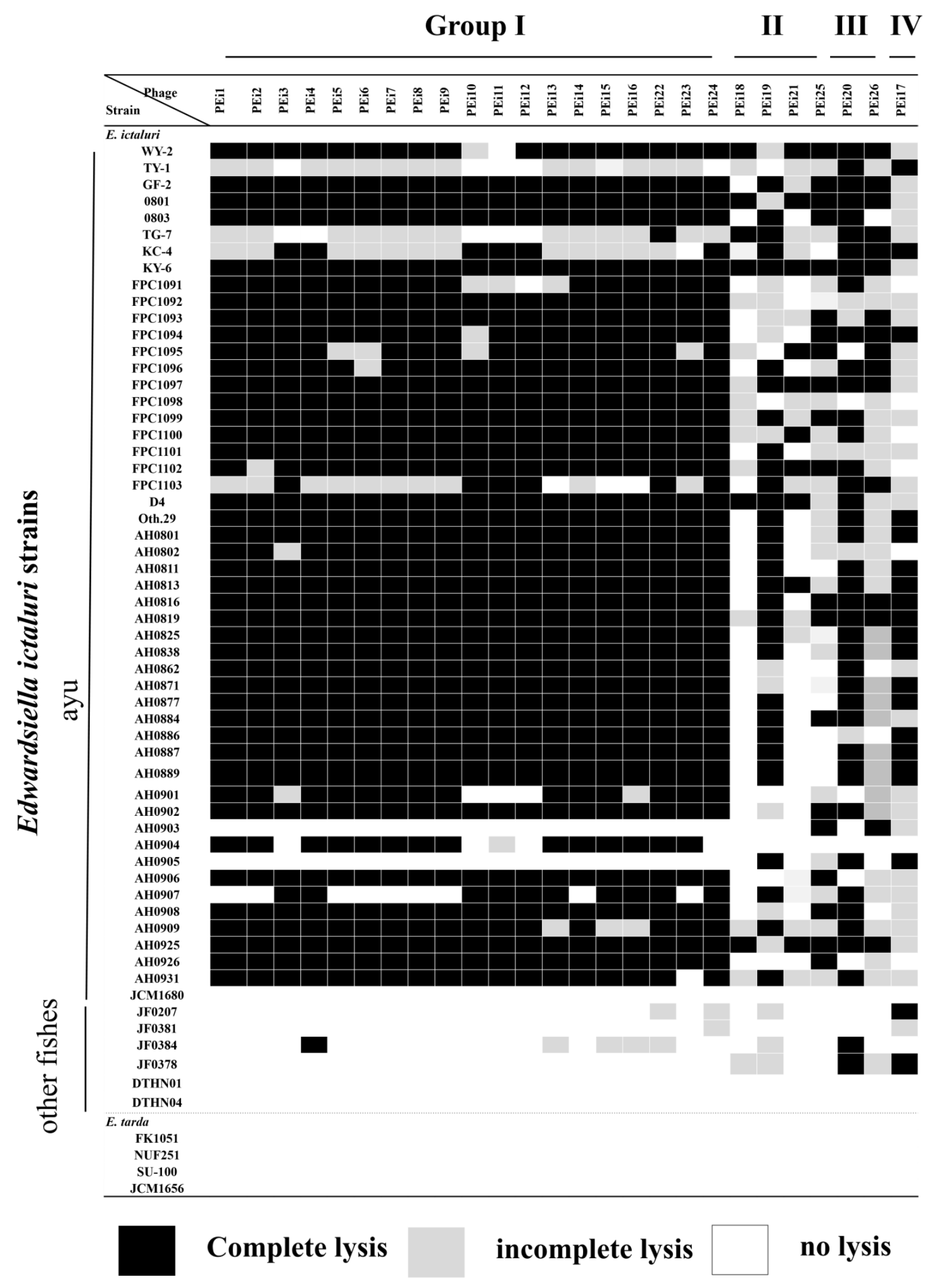

Fig. 3: Host range of the isolated phages against representative Edwardsiella ictaluri strains.m: complete lysis, 煎: incomplete lysis, $\square$ : no-lysis. 


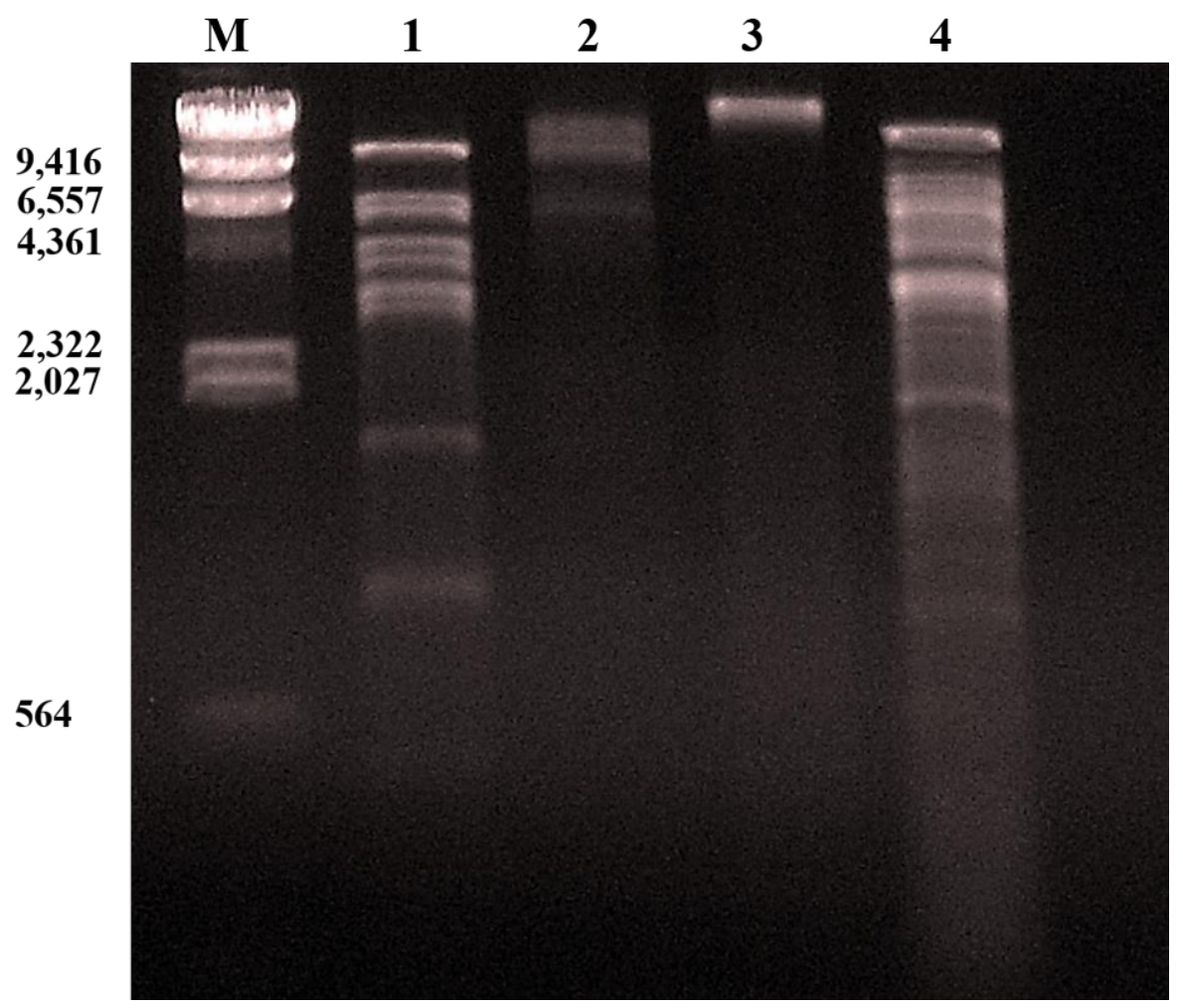

Fig. 4: Agarose gel electrophoresis of restrictions digest analysis of representative Edwardsiella ictaluri bacteriophages after treatment with EcoRI. M: Marker ( $\lambda /$ Hind III digests), 1: PEi1 (Group I) phage, 2 : PEi19 (Group II) phage, 3: PEi20 (Group III) phage and 4: PEi17 (Group IV) phage.

\section{DISCUSSION}

The current study describes the isolation of 26 bacteriophages specific to $E$. ictaluri isolated from wild ayu, showing no clinical signs, and its environment (water, and mud), using enrichment method. These phages may contribute to lessening the incidence of $E$. ictaluri outbreaks. Since $E$. ictaluri is also reported to survive in water and pond bottom sediments for a relatively long time (Plumb and Quinlan, 1986), there is a reason to suspect that E. ictaluri- specific phages may persist in the environment. In our previous work, a semiquantitative method was conducted, on a monthly basis, for the estimation of E. ictaluri phage concentration using $1,10,50,100,200$, and $400 \mathrm{ml}$ river water. We could detect $E$. ictaluri phages even in $1 \mathrm{ml}$ river water (Hassan et al., 2012). Moreover, E. ictaluri phages could be isolated throughout a one-year study period indicating the coexistence of E. ictaluri and its phage(s) in the river water (Hassan et al., 2012). This result comes with the idea that bacteriophages are ubiquitous in the environments inhabited by their respective bacterial host(s) (Kutter and Sulakvelidze, 2005). In addition,Walakira and coworkers described the isolation and the characterization of two unique E. ictaluri-specific phagesof family Siphoviridae; ФeiAU (eiAU) and ФeiDWF (eiDWF) from aquaculture ponds with a history of ESC (Walakira et al., 2008). Sebsequently, theses phages were sequenced (Carrias et al., 2011).

In the present study, the enrichment method, used for the phage isolation from ayu and its environment, was proved to be effective. Also, Walakira et al. (2008) isolated E. ictaluri-specific phages by concentrating viruses from pond water samples by ultrafiltration and enriching for E. ictaluri-specific bacteriophages via enrichment in log-phase bacterial broth cultures.

The phages described herein displayed plaques of different sizes (0.3-8 $\mathrm{mm}$ in diameter) on the double agar layer. However, the transmission electron microscopy revealed similar morphotypes, classified as members of Myoviridae by the phage taxonomy (Ackermann, 2005). All the isolated phages belonged to family Myoviridae that had icosahedral or elongated head and a contractile tail structure that is more or less rigid, long and relatively thick, and consists of a central core built of stacked rings of six subunits and surrounded by a helical contractile sheath, which is separated from the head by a neck. During contraction, sheath subunits slide over each other and the sheath becomes shorter and thicker, which brings the tail core in contact with the bacterial plasma membrane. Myoviruses tend to be larger than other groups and include some of the 
largest and most highly evolved tailed phages (Martha and Andrew, 2009).

All phage isolates were DNA phages as they were digested by DNase I but not by RNase A. The phage nucleic acids were larger than $20,000 \mathrm{bp}$ and reached up to 43,378 bp in PEi21 (Yasuike et al., 2014). Similar data was reported by Carrias and coauthors who reported that the whole genomes of E. ictaluri phages; eiAU, eiDWF, and eiMSLS were $42.80 \mathrm{kbp}$, $42.12 \mathrm{kbp}$, and $42.69 \mathrm{kbp}$, respectively (Carrias et al., 2011).

The restriction digests using EcoRI showed that the cleaved nucleic acids of the phages exhibited various restriction patterns among the different phage groups and same pattern among individuals of the same group, however, group III phages that is represented by PEi20 and PEi26 was not digested by endonucleases, and this may be due to methylations or glucosylations on the phage DNA (Nelson and McClelland, 1991). Based on these results, the isolated phages were classified into four groups; the first group which was the main group and contained 19 phage isolates. It was widespread as it was isolated from ayu kidneys, river water, and mud forming clear round plaques having sharp edges with an average diameter of 1.5-2.5 $\mathrm{mm}$ and the host bacteria were E. ictaluri isolated from wild ayu. The second group represented by five phage isolates, produced big hazy plaques (around 5-8 $\mathrm{mm}$ in diameter) and their host was a resistant E. ictaluri isolate evolved both in vivo and in vitro. The third group included two phage isolates that were isolated from river mud only. Phages of this group displayed small plaques $(0.5-1 \mathrm{~mm}$ in diameter) and the host bacteria is a resistant $E$. ictaluri isolate evolved in vivo. The fourth group consisted of only one phage isolate that was isolated from river water and its host cell was a resistant $E$. ictaluri, retrieved in vitro, and form very small round plaques with average 0.3-0.4 $\mathrm{mm}$ in diameter. Some of the isolated phages produced clear plaques suggesting that they may be lytic and virulent to E. ictaluri. The lytic characters of a representative phage was discussed in a previous work (Yasuike et al., 2015) who reported the absence of lysogeny- related genes such as integrase, repressor $\mathrm{CI}$, regulatory protein $\mathrm{CII}$ and anti-repressors in E. ictaluri phage, PEi21.

Phage typing is a well-known sensitive tool for establishing relationships among intra-species of bacteria (Pfaller, 1991). Interestingly, all the tested $E$. ictaluri strains $(\mathrm{n}=57)$, isolated from apparently healthy wild ayu at different localities in Japan (Hassan et al., 2012), were sensitive to the isolated phages but with different degrees resulting in twenty-five phage types $(1 \sim 25)$, with major phage types; phage type one represented by 13 E. ictaluri strains, and phage type two represented by $12 E$. ictaluri-sensitive strains. The variation in susceptibility among host strains may be largely due to differences in host receptor sites, modification or loss of receptor molecules, or other host resistant mechanisms such as abortive infection (Levin and Bull, 2004). It is noteworthy to mention that $E$. ictaluri strains isolated from catfish in the USA (one isolate), Indonesia $(n=4)$ or Vietnam $(n=2)$ exhibited very limited susceptibility to the present phages. In addition, E. tarda, the most closely related species to E. ictaluri (Waltman et al., 1986), was not susceptible to any of the phages examined in the current study., indicating that all the isolated $E$. ictaluri-specific phages may be a useful diagnostic tool for E. ictaluri strains isolated from nearby geographic but not distant areas.

Screening the lytic activity of these phages, revealed that PEi22 was one of the most potent phages lysing 52 out of the 57 strains examined, in which 42 strains were lysed efficiently indicated by clear plaques. Also, PEi20 could lyse 49 out of the 57 strains. At the other end of the range, PEi18 infected only 18 strains eliciting clear plaques with only six strains. Compared to chemotherapeutants that have a broad-spectrum activity on different species or strains (Nelson, 2004), the use of a strain-specific phage may be not effective to control the pathogen in question, yet a 'cocktail' of E. ictaluri specific phages may have better efficiency as a biological control strategy (O'Flynn et al., 2004). A combination of phages with different lytic properties may thus provide the best starting point for further exploration of the potential of phage therapy for controlling pathogenic bacteria. In the present study, we isolated a suite of lytic E. ictaluri phages that were able to infect and lyse a wide range of $E$. ictaluri strains. The most potent phages were PEi4, PEi19, PEi20, PEi22, and PEi26 which together lyse almost all E. ictaluri strains examined. Therefore, the mixture of these powerful phages, having a prominent lytic effect, may help for control of $E$. ictaluri infection in cultured fish. In a prelimnary study to explore the role of the isolate phages to control E. ictaluri infection in ayu, when ayu was first injected with virulent $E$. ictaluri strain and onehour later injected with a mixture of these phages, a delayed mortality, in comparison with the control was noticed. On the other hand, high protection was observed in fish that was first injected with phages and then injected with the pathogen. These results endorsed the use of these phages in phage therapy of E. ictaluri infection of ayu (Mahmoud and Nakai, 2012).

In conclusion, we could isolate 26 E. ictaluri-lytic phages from wild ayu and its surrounding environment, and identify these phages both morphologyically and by the restriction enzyme that is a prerequiste for evaluating the phage potential as a biological control of a pathogenic host. Also, these phages served in the differentiation of various $E$. 
ictaluri strains isolated from different localities all over Japan. Furthermore, their promising strong lytic property both in vitro and the in vivo preliminary challenge provide a foundation for future exploration of their potential in treatment of $E$. ictaluri infection in fish farms to overcome the disadvantages of using antibiotics including their residues, side effects or developing of antibioticresistant strain(s).

\section{REFERENCES}

Ackermann, H.W. (2005): Bacteriophage Classification. In: Kutter, E., Sulakvelidze, R. (Eds.), Bacteriophage Biology and applicationCRC Press, Boca Raton, Florida, USA, pp. 65-87.

Carlson, H. (2005): Common Techniques and Methodological Approaches. In: Kutter, E., Sulakvelidze, R. (Eds.), Bacteriophage Biology and application. CRC Press, Boca Raton, Florida, USA., pp. 414-471.

Carrias, A.; Welch, T.J.; Waldbieser, G.C.; Mead, D.A.; Terhune, J.S. and Liles, M.R. (2011): Comparative genomic analysis of bacteriophages specific to the channel catfish pathogen Edwardsiella ictaluri. Virology Journal 8:

Crumlish, M.; Dung, T.; Turnbull, J.; Ngoc, N. and Ferguson, H. (2002): Identification of Edwardsiella ictaluri from diseased freshwater catfish, Pangasius hypophthalmus (Sauvage), cultured in the Mekong Delta, Vietnam. J. Fish. Dis 25: 733-737.

Ferguson, H.W.; Turnbull, J.F.; Shinn, A.; Thompson, K.; Dung, T.T. and Crumlish, M. (2001): Bacillary necrosis in farmed Pangasius hypophthalmus (Sauvage) from the Mekong Delta, Vietnam. Journal of Fish Diseases 24: 509-513.

Hassan, E.S.; Mahmoud, M.M.; Dung, N.H.; Yuasa, $K$. and Nakai, T. (2010): Serological Characterization of Edwardsiella ictaluri Strains Isolated from Wild Ayu Plecoglossus altivelis. Fish Pathology 45: 43-46.

Hassan, E.S.; Mahmoud, M.M.; Kawato, Y.; Nagai, T.; Kawaguchi, O.; Iida, Y.; Yuasa, K. and Nakai, T. (2012): Subclinical Edwardsiella ictaluri Infection of Wild Ayu Plecoglossus altivelis. Fish Pathology 47: 64-73.

Hawke, J.P. (1979): A Bacterium Associated with Disease of Pond Cultured Channel Catfish, Ictalurus punctatus. Journal of the Fisheries Research Board of Canada 36: 1508-1512.

Hawke, J.P.; McWhorter, A.C.; Steigerwalt, A.G. and Brenner, D.J. (1981): Edwardsiella ictaluri sp. nov., the Causative Agent of Enteric Septicemia of Catfish. International Journal of Systematic and Evolutionary Microbiology 31: 396-400.
Kasornchandra, J.D.; Lancaster, C.; Gudkovs, N. and McDonald, W. (1987): Edwardsiella ictaluri from walking catfish, Clarias batrachus L. in Thailand. J. Fish Dis. 10: 137-138.

Kawato, Y.; M., Y.; Nakamura, Y.; Shigenobu, Y.; Fujiwara, A.; Sano, M. and Nakai, T. (2015): Complete genome sequence analysis of two Pseudomonas plecoglossicida phages, potential therapeutic agents. Appl Environ Microbiol 81: 874-881.

Kelly, E.; Martin, P.A.J.; Gibson-Kueh, S.; Morgan, D.L.; Ebner, B.C.; Donaldson, J.; Buller, N.; Crook, D.A.; Brooks, S.; Davis, A.M.; Hammer, M.P.; Foyle, L.; Hair, S. and Lymbery, A.J. (2018): First detection of Edwardsiella ictaluri (Proteobacteria: Enterobacteriaceae) in wild Australian catfish. Journal of Fish Diseases 41: 199-208.

Kent, M.L. and Lyons, J.M. (1982): Edwardsiella ictaluri in the green knife fish, Eigemannia virescens. Fish Health News 2: ii.

Keskin, O.; Secer, S.; Izgür, M.; Türkyilmaz, S. and Mkakosya, R.S. (2004): Edwardsiella ictaluri infection in Rainbow Trout (Oncorhynchus mykiss). Turk. J. Vet. Anim. Sci. 28: 649653.

Klesius, P.; Lovy, J.; Evans, J.; Washuta, E. and Arias, C. (2003): Isolation of Edwardsiella ictaluri from Tadpole Madtom in a Southwestern New Jersey River. Journal of Aquatic Animal Health 15: 295-301.

Kutter, E. and Sulakvelidze, A. (2005): Bacteriophage Biology and applicationCRC Press, Boca Raton, Florida, USA.

Levin, B.R. and Bull, J.J. (2004): Population and evolutionary dynamics of phage therapy. Nat Rev Microbiol 2: 166-173.

Mahmoud, M.M. and Nakai, T. (2012): Bacteriophage therapy of Edwardsiella ictaluri infection in ayu Plecoglossus altivelis. In: Massive Conferences and Trade Fairs, City, pp. 160-169.

Martha, R.J.C. and Andrew, M.K. (2009): Bacteriophages methods and protocol, volume 1: Isolation, characterization and interactions Humana press.

Nagai, T.; Iwamoto, E.; Sakai, T.; Arima, T.; Tensha, K.; Iida, Y.; Iida, T. and Nakai, T. (2008): Characterization of Edwardsiella ictaluri Isolated from Wild Ayu Plecoglossus altivelis in Japan. Fish Pathology 43: 158163

Nelson, D. (2004): Phage taxonomy: we agree to disagree. Journal of Bacteriology 186: 70297031.

Nelson, M. and McClelland, M. (1991): Site-specific methylation: effect on DNA modification methyltransferases and restriction endonucleases. Nucleic Acids Research 19: 2045-2071. 
O'Flynn, G.; Ross, R.P.; Fitzgerald, G.F. and Coffey, A. (2004): Evaluation of a cocktail of three bacteriophage for biocontrol of Escherichia coli 0157: H7. Appl. Environ. Microbiol 70: 3417-3424.

Pfaller, M.A. (1991): Typing methods for epidemiologic investigation. In: Balows, W., Hausler, J., Herrmann, K.L., Isenberg, H.D., Shadomy, H.J. (Eds.), Manual of clinical microbiologyAmerican Society for Microbiology, Washington. DC., pp. 171182.

Plumb, J.A. and Quinlan, E.E. (1986): Survival of Edwardsiella ictaluri in pond water and bottom mud. The Progressive Fish-Culturist 48: 212-214.

Sakai, T.; Kamaishi, T.; Sano, M.; Tensha, K.; Arima, T.; Iida, Y.; Nagai, T.; Nakai, T. and Iida, T. (2008): Outbreaks of Edwardsiella ictaluri Infection in Ayu Plecoglossus altivelis in Japanese Rivers. Fish Pathology 43: 152-157.

Sakai, T.; Yuasa, K.; Sano, M. and Iida, T. (2009): Identification of Edwardsiella ictaluri and $E$. tarda by species-specific polymerase chain reaction targeted to the upstream region of the fimbrial gene. J. Aquat. Anim. Health 21: 124- 132.

Walakira, J.K.; Carrias, A.A.; Hossain, M.J.; Jones, E.; Terhune, J.S. and Liles, M.R. (2008): Identification and characterization of bacteriophages specific to the catfish pathogen, Edwardsiella ictaluri. J Appl Microbiol 105: 2133-2142.
Waltman, W.D.; Shotts, E.B. and Blazer, V.S. (1985): Recovery of Edwardsiella ictaluri from danio (Danio devario). Aquaculture 46: 63-66.

Waltman, W.D.; Shotts, E.B. and Hsu, T.C. (1986): Biochemical characteristics of Edwardsiella ictaluri. Applied and Environmental Microbiology 51: 101-104.

Yasuike, M.; Kai, W.; Nakamura, Y.; Fujiwara, A.; Kawato, Y.; Hassan, E.S.; Mahmoud, M.M.; Nagai, S.; Kobayashi, T.; Ototake, M. and Nakai, T. (2014): Complete genome sequence of the Edwardsiella ictaluri-specific bacteriophage PEi21, isolated from river water in Japan. Genome Announc. 2: e0022800214

Yasuike, M.; Nishiki, I.; Iwasaki, Y.; Nakamura, Y.; Fujiwara, A.; Sugaya, E.; Kawato, Y.; Nagai, S.; Kobayashi, T.; Ototake, M. and Nakai, T. (2015): Full-genome sequence of a novel myovirus, GF-2, infecting Edwardsiella tarda: comparison with other Edwardsiella myoviral genomes. Arch Virol

Ye, S.; Li, H.; Qiao, G. and Li, Z. (2009): First case of Edwardsiella ictaluri infection in China farmed yellow catfish Pelteobagrus fulvidraco. Aquaculture 292: 6-10.

Yuasa, K.; Kholidin, E.B.; Panigoro, N. and Hatai, K. (2003): First isolation of Edwardsiella ictaluri from cultured striped catfish Pangasius hypophthalmus. Fish. Pathol. 38: 181-183.

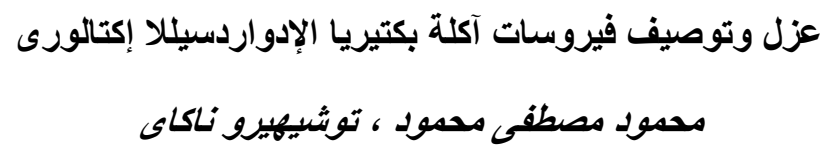

E-mail: $\underline{\text { mahmoud88@aun.edu.eg Assiut University web-site: } \underline{w w w . a u n . e d u . e g}}$

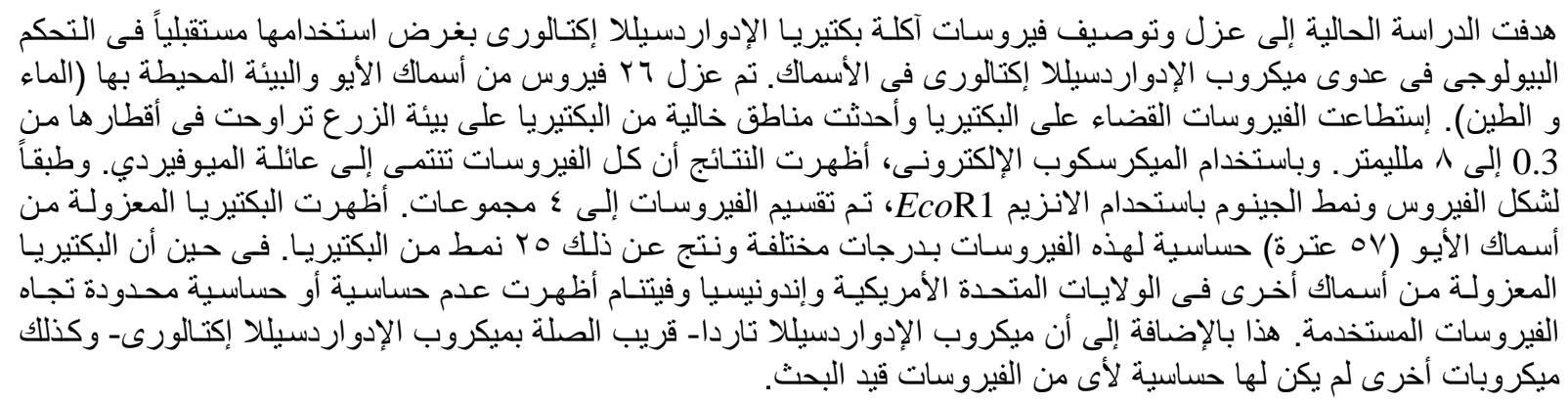

